\title{
自然とのふれあいと創造性
}

\section{Nature Experience and Creativity}

\author{
大寺 俊紀* Toshinori ODERA
}

\section{1. 子ども, 自然, 芸術問題取組みの経緯}

私が「子どもと自然, 芸術」の問題に注目し，取組みを 開始したのが今から丁度 30 年前。当時はなんでも使い捨 て, 新しいものは全て良いという風潮で, 自然環境はどん どん破壊され，子どもの教育上由々しき影響があることに 気付く人, 自然や芸術の本物との出会いが創造性教育で重 要な問題点だと言う声もわずかであった。

オリンピックや万博, 列島改造で日本中が忘我の状態に あり, 既にテレビと塾が従来の遊びを奪い変えてしまい, 気付いたときには周辺には遊べる海も川もなくなっていた。 都会の子どもに絵を教えていた私は，子どもがテレビや室 内遊び, 道路やアパートの階段などで遊ぶのが殆どで, 自 然の中での遊びを知らないため, その「知識」は抽象的で 体験や感動がなく, 創造性にも欠けると気付かされた。彼 らの描く絵は画一的, 感動のないもので, 非常に飽きやす い傾向が見られた。子どもたちは大地に根を張らない水栽 培の野菜のようで自立性はなく創造性は枯渇していた。

そこでスタートしたのが「自然の会」。約 200 人の子ど もと 50 人のリーダーで毎週野山で自然に触れ合い，そこ で体験したこと，感じたことを作品にするという造形指導 を 10 年余り続けた。 1 年間, 田植えから稲刈り, 脱穀, 餅つきまでを経験したり， $2-3$ 週間のサバイバルキャン プを行うなどの活動は, 子どもたちを大変たくましく育て, 社会に出てからの彼らは大変積極的でリーダーシップを持 ち, 活躍しているということをよく聞いている。

その間 10 数年が経ち, 世界中で自然回帰指向が強まり, 野外活動施設も増えたが, 何処へ行っても, 同じマニュア ルで, ゲームソングばかりという実態であったので, 創造 的な施設, 創造的な活動, 自然と芸術の関連を重視すべき ことを訴えるべく「創造の森」を開設した。

そこは全て手作りで, 山小屋やキャンプ場, テントサイ ト,グランドや農園などを作り, 造形作家による「野外造 形作品展」も二度開催した。作家は全て現地に宿泊して製 作, 森全体に「環境芸術」が展示された。17 年前のこと である。子どもたちはアーティストの作品に大変な刺激を
受け,まけじと巨大な環境アートに取り組んだ。

彼らは, 動物追跡や野鳥観察などの体験を広場一杯に 「アースワーク」するという経験もした。光の芸術, 音の 作品なども製作した。出品作家も多数指導して下さった。 子どもたちが直接芸術家の作品に触れ, 又指導を受けるこ とは大変な感動を与えたと思う。彼らの行動は大変いきい きとしたものであった。強調性, 忍耐力にも富み, 豊かな 感受性を養ったと考えられる。この時期の会員で, 現在国 連などの機関で自然保護活動に従事しているものが多い。

次に創造の森での経験を基にして 10 年前に現在の地に 移転完成したのが「創造の森子ども美術館」である。

\section{2. 子ども美術館の内容と展開}

「創造の森」に進んで以来対象を会員だけから一般に移 行しつつあった会は, 以後 $90 \%$ 一般対象の活動に変更 し, 種々の企画を計画して多くの子どもたちに場と機会を 提供してきた。又，第一期で自然回帰運動，第二期で野外 活動施設の創造性を訴えてきた会は, 第三期として美術館 と自然と体験の一体化を訴え, 実践してきた。

\section{(1) 現代美術展示}

2ヘクタールの森全体に野外造形作品を展示。毎年平均 20 人が参加。石, 鉄などの野外彫刻のほか「環境芸術」 も多く, 広場, 茂み, 散策路, 岩場, 木立などに様々の作

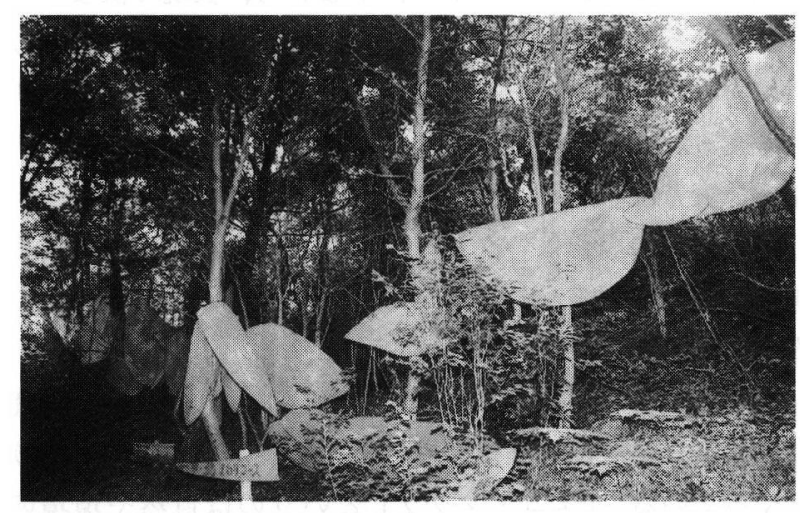

写真一 1 協同製作「忍者やしき」 
品が展示された。

これらは一般入場者, 団体入場者（学校の遠足）は勿論, 特に造形講座，イベント，自然と造形キャンプ参加者に関 心が持たれ，造形教育活動の中で大きな役割を果たしてき た。アースワーク，竹の造形，丸太の造形，など触れたり， 動かすこともできる作品，木立や岩場のインスタレーショ ン作品などは子どもたちの造形作品への関心を高め，自分 たちも挑戦したいという意欲を強く喚起した。

(2) 種々のイベント, キャンプ, 造形教室（講座）

丸太の造形作品をヒントに子どもたちも丸太の恐竜作品 を作るなど，作家の作品との連動で種々の造形講座や作品 指導（キャンプ，日㷌り）を実施。針金，ラス網の造形， 楽器の作品, その他「木の上の家」「とりで」「吊橋」「か くれが」などの協同作品，「タヌキの巣」などの自然観察 （ウオッチング）からの作品などもあった。

学校からの見学や講習会研修会への講師派遗養成も多数 で，学校美術への影響も大であったと考える。

(3) 日常活動, 友の会活動など

(1)，(2)とは別に，入場者に対する造形指導（教室）や 友の会会員向けの造形活動, 自然観察, ウオッチング活動 も継続してきた。

一般入場者の造形では, クレイワークや木の枝, 板，竹 などを使ったハンドクラフト，造形作品。季節的には，と んぐりの造形, 紙すき, リース作りなども人気があった。 子ども会などの団体がよく利用したが創作活動が出来るこ とが好評であった。

\section{3. 自然との親しい関係}

今まで既に触れてきたが，私は創造教育において自然と のふれあい体験が極めて重要であると考えている。現在で も都会の子どもたちに造形指導を行っているので，単に素 材を与えるだけでも造形指導が可能であることはわかって いるが，それらは極めてデジタルで，感動のうすいもので ある。ゲーム感覚で行っていると言える。

自然との深いかかわりを経験した子どもは，その美しさ

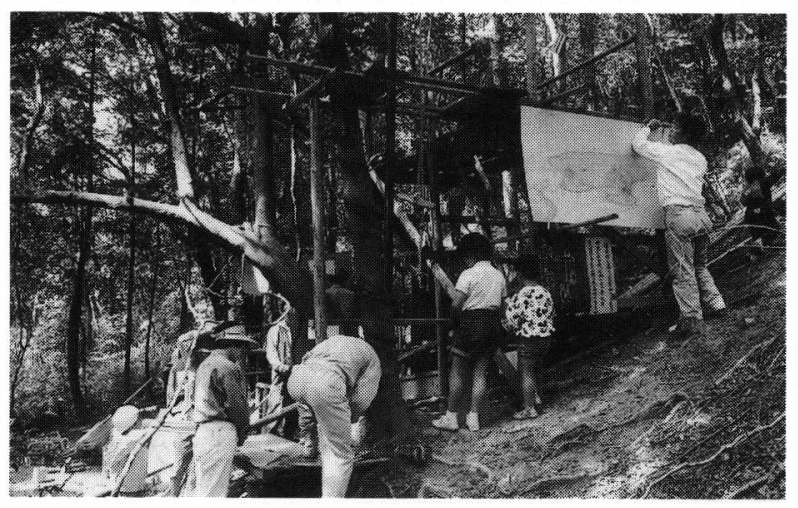

写真－２＼cjkstart環境アート作品（北林佳代子 作）
や優しさに感動する心が育つ。それは慈愛の心でもある。 この素晴らしい自然を創造された方への畏敬の念にも通じ る。人間性で最も大切なへりくだりの気持ちである。この 情操教育を経験しないで育った青少年は, 人間性の形成に バランスを欠いていると言え, 底の浅さも感じ, 大変危険 なリーダーとなる恐れもある。

又，昨今の子どもは「空想力」が豊かであることは認め ることができるが，それらは極めて画一的であり，リアリ ティーや情感に欠けているのが特徴である。木や草や岩, 日の出や日没の太陽，さわやかな草原の風，そしてそれら と組合わさり一体となっていく野外での造形作品との出会 い,これらが干乾びたような，かつ独善的な世界に閉じこ もりがちな子どもたちに「息吹」を与える。

又, 自然観察やタヌキウオッチングなどの経験, 吊橋や 木の上の家など大スケールの協同の遊びの作品を経験する と，優しさ，暖かさ，集中力，根気，協調性などが強めら れる。自然の素材や道具を「工夫する」ことから得られる 力はデジタルな造形指導では得られない創造力である。こ れらは，いわゆる「自然観察会」だけでは不十分である。

きちんと整備された野外美術館や手を触れてはいけない 「観察施設」だけではなく，様々の創造的な遊びを体験で きる場がこれから益々必要である。

\section{4. 今後の展開}

今迄，子ども美術館では「環境芸術」的な作品の展示も 多数あった。石彫，木彫，鉄の作品なども，それぞれ設置 場所を定めて製作し搬入するというようになされてきたの で，自然環境と芸術作品のバランスを配慮してきたが，そ れは単に作品をよく見せるというよりも両者の一体美をね らって来た。又, 観客 (子ども) の創作意欲を喚起するこ とを狙っていたが，伝統的な彫刻と違い，環境芸術は子と もと芸術を一層近付けたと思う。

当館は 1995 年 11 月末に一旦閉館し, 今後移転工事を行 い, 従来からあった地元と泉南市のキャンプ場に誘致合併 される。泉南市立キャンプ場は，これを機会に内容を一新， 体験的野外造形施設（体験美術館）として再出発する。

最後に, 今後の課題としてあげたいのは, 次の 2 点であ る。第一は「ソフトの充実」。創造的で, 柔軟な運営, 企 画，指導のできる人材が必要。そして，芸術家のネットワー クも必要。子ども美術館では十年間でのべ 400 人以上の出 品や指導, 出演などがあった。第二は, 施設の柔軟な運営。 今迄，吊橋や林全体を細い廃材で作品にする他，木上の家， 丸太の恐竜, 野外ステージなどもインスタレーション作品 化し，地下室を設けたり，隣の建物と連結して迷路にした りと, 毎年次々と変化させてきた。都会の公園や広場に巨 大なモニュメントを置いただけの施設，建物だけが立派な 「ハード優先」の施設だけは避けたいものである。 